\title{
Identifikasi Caesio cuning berdasarkan Karakterisasi Morfometrik dan DNA Barcoding yang didaratkan di Pasar Ikan Muara Baru, Jakarta
}

\author{
Muhammad Fahmi Zuhdi* dan Hawis Madduppa \\ Departemen IImu dan Teknologi Kelautan, Fakultas Perikanan dan IImu Kelautan, IPB University \\ Jl. Raya Dramaga, Kampus IPB Dramaga Bogor, Jawa Barat 16680 \\ Email: fahmizuhdi@apps.ipb.ac.id
}

\section{Abstract \\ Identification of Caesio cuning using Morphometric characteristic and DNA barcoding Analysis (COI Gene) Landed in Muara Baru Market, Jakarta}

\begin{abstract}
Yellow-tailed fish (Caesio cuning) have morphologically similarities with Lutjanidae families, it causes ambiguity on species authentication process. The process of species identification using morphological characteristic does not provide a precise information related to the species. This study was aimed to identify the morphometric and molecular of Yellow-tailed fish (Caesio cuning) which landed on Muara Baru Fish Market, Jakarta using COI gene. A total 30 fishes were observed their nineteen morphometric characters, and 1 fish sample was taken from the fins for DNA extraction, amplification using PCR method, electrphoresis visualization, and sequensing. Sample was analyzed by MEGA 6 software. Based on morphological analysis showed that sampel are Yellow-tailed fish which part of Caesio genus and Caesionidae family. While, genetic analysis using $\mathrm{COI}$ gene showed has similarities with database of Genbank NCBI. It can be concluded that identification using morphological character and DNA barcoding methode showed the species belong to Yellow-tailed fish (Caesio cunning).
\end{abstract}

Keywords : Morphometric; DNA Barcodin; Caesio cuning

\begin{abstract}
Abstrak
Ikan Ekor Kuning (Caesio cuning) memiliki kemiripan morfologi dengan anggota famili Lutjanidae lainnya, hal tersebut menyebabkan kesulitan dalam proses autentikasinya. Proses identifikasi pada suatu spesies menggunakan karakteristik morfologinya belum mampu memberikan informasi yang akurat terkait spesies tersebut. Penelitian ini bertujuan untuk mengidentifikasi ikan ekor kuning (Caesio cuning) yang didaratkan di Pasar Muara Baru, Jakarta melalui kajian karakteristikmorfometrik dan DNA barcoding menggunakan marka gen COI. Total 30 ikan diamati karakter morfometriknya, dan 1 sampel ikan diambil bagian siripnya untuk dilakukan ekstraksi DNA, amplifikasi PCR, elektroforesis, sekuensing dan dianalisis menggunakan aplikasi MEGA 6. Hasil analisis morfologi menunjukkan sampel ikan berasal dari genus Caesio dan termasuk famili Caesionidae. Sedangkan berdasarkan analisis secara molekuler menggunakan marka gen COI, didapatkan hasil bahwa spesies yang diamati (Caesio cuning) memiliki kemiripan dengan database GenBank NCBI. Dapat simpulkan bahwa identifikasi secara morfologi dan DNA menunjukkan bahwa spesies yang di peroleh yaitu lkan ekor kuning (Caesio cuning).
\end{abstract}

Kata Kunci : Morfometrik; DNA barcoding; Caesio cuning

\section{PENDAHULUAN}

Ikan demersal merupakan salah satu sumber daya ikan yang menjadi primadona untuk ditangkap dan dijadikan sebagai bahan konsumsi. Ditjen Perikanan (1998) lebih lanjut mengungkapkan bahwa perairan karang di Indonesia memiliki paling sedikit 10 
famili utama penyumbang produksi perikanan yaitu Holocentridae, Serranidae, Siganidae, Scaridae, Lethirindae, Priachantidae, Labridae, Lutjanidae, Haemulidae dan Caesionidae. Di antara beberapa famili tersebut, Caesionidae seperti ikan ekor kuning merupakan kelompok ikan yang dapat dieksploitasi secara komersil. Data BPS (2008) melaporkan kenaikan produksi ikan ekor kuning mengalami peningkatan 262 ton dari tahun 2003 sampai tahun 2007. Hal tersebut tentu mengakibatkan turunnya populasi ikan dan mengancam kelestarian sumber daya ikan tersebut.

Famili Caesinoidae merupakan anggota dari ordo Perciformes yang hidup di perairan laut dan hanya ditemukan di perairan tropis Indo-Pasifik (Carpenter, 2001). Jenis ikan dari famili Caesionidae, salah satunya ikan ekor kuning yang memiliki karakteristik khusus berupa warna yang mencolok, sebagian besar memiliki garis-garis berwarna kuning. Selain itu, ikan ekor kuning sering membentuk gerombol (Carpenter, 1998). Menurut Jhonson (1980) ikan dari famili Caesionidae memiliki hubungan yang sangat dekat (sister group) dengan ikan-ikan dari famili Lutjanidae. Karena kemiripan morfologinya yang sangat mirip tersebut, membuat masyarakat sulit membedakan antara kedua ikan tersebut.

Karakteristik morfologi ikan ekor kuning yang hampir sama tersebut dapat menimbulkan kekeliruan dalam proses identifikasi spesies. Proses tersebut memerlukan akurasi yang tinggi untuk menghindari kesalahan dalam autentikasi spesies ikan. Oleh karena itu, metode DNA Barcoding digunakan karena mampu membantu proses identifikasi spesies secara cepat dan tepat. Salah satu metode yang dikembangkan oleh Herbert et al. (2003) untuk validasi spesies adalah marka gen $\mathrm{COI}$, yang terletak pada segmen mitokondria sehingga mampu menelusuri variasi basa nukleotida pada setiap spesies. Tujuan penelitian ini adalah mengidentifikasi karakter morfometrik dan DNA ikan ekor kuning (Caesio cuning) menggunakan marka gen COI.

\section{MATERI DAN METODE}

Pengambilan sampel ikan dilakukan di Pasar Ikan Modern Muara Baru, Jakarta. Analisis morfometrik ikan dilakukan di Pasar Ikan Modern Muara Baru, Jakarta. Analisis molekuler ikan dilakukan di Laboratorium Biodiversitas dan Biosistematika Kelautan Fakultas Perikanan dan IImu Kelautan Institut Pertanian Bogor.

Pengambilan sampel ikan dilakukan dengan mengambil langsung di Pasar Ikan Modern Muara Baru. Setiap sampel ikan di ambil foto morfologinya menggunakan kamera, kemudian diukur karakter morfometriknya. Satu sampel ikan di ambil jaringan bagian sirip ekor dan diawetkan menggunakan etanol 96\%. Sampel ikan kemudian di simpan di Laboratorium dibawah suhu $-20^{\circ}$ C untuk dilakukan pengamatan DNA ikan.

Analisis morfologi ikan ekor kuning dilakukan dengan cara identifikasi secara visual yaitu mengamati ciri-ciri morfologi berupa bentuk tubuh, warna dan ukuran tubuh ikan. Identifikasi spesies ikan mengacu pada buku identifikasi (Carpenter, 1998), (White et al. 2013).

Total 30 sampel ikan diamati karakter morfometriknya berdasarkan metode dari Fitriadi et al., (2012). Adapun karakter morfometrik yang diamati antara lain: panjang total (TL), panjang standard (PS), panjang kepala (PK), tinggi badan (TB), tinggi pangkal ekor (TPE), diameter mata (DM), jarak antar mata (JAM), lebar badan (LB), panjang sebelum sirip dorsal (PSSD), panjang sebelum sirip ventral (PSSV), panjang sebelum sirip anal (PSSA), panjang dasar sirip dorsal (PDSD), panjang dasar sirip ventral (PDSV), panjang dasar sirip anal (PDSA), panjang dasar sirip pectoral (PDSP), panjang sirip ekor atas (PSEA), panjang sirip ekor tengah (PSET) dan panjang sirip ekor bawah (PSEB) (Gambar 1).

Ekstraksi DNA bertujuan untuk menghancurkan sel dan memisahkan DNA pada sampel. Pada penelitian ini $25 \mathrm{mg}$ jaringan diambil untuk diekstraksi DNA-nya menggunakan gSYNCTM DNA Extraction Kit. Lokus gen yang digunakan yaitu 
mitochondrial cytochrome c oxidase subunit I (COI). Amplifikasi DNA menggunakan metode Polymerize Chain Reaction (PCR) merupakan reaksi memperbanyak (replikasi) DNA secara enzimatik. Primer yang digunakan untuk amplifikasi ikan yaitu FishF 1 (5'-TCAACCAACCACAAAGACATTGGCAC-

3'); FishR1 (5'-TAGACTTCTGGGTGGCCAA AGAATCA-3') (Ward et al. 2005). Komponen dalam PCR Mix adalah 12,5 $\mu \mathrm{l} \mathrm{My} \mathrm{taq,} \mathrm{1,25} \mathrm{\mu l}$ Primer, $9 \mu \mathrm{lddH} 20,1 \mu \mathrm{l}$ DNA Template. Proses amplifikasi DNA menggunakan DIAB Mastercycler DNA Engine Thermal Cycler. Proses awal amplifikasi DNA yaitu Tahap denaturasi pada suhu $94^{\circ} \mathrm{C}$ selama 30 detik, penempelan primer (annealing) pada suhu $50^{\circ} \mathrm{C}$ selama 1 menit, pemanjangan segmen DNA (extension) pada suhu $72^{\circ} \mathrm{C}$ selama 1 menit, dan tahap akhir (final extension) pada suhu $72^{\circ} \mathrm{C}$ selama 7 menit dengan 38 siklus.

Elektroforesis adalah pemurnian molekul dengan cara pemisahan senyawa kimia berdasarkan laju pergerakan molekul dalam aliran listrik yang bertujuan untuk mengetahui kualitas DNA dari hasil PCR (Madduppa, 2014). Proses elektroforesis dimulai dengan membuat gel agarose 1\% menggunakan pewarna GelRedTM (Biotium ${ }^{\circledR}$ ) sebagai media elektroforesis. Hasil PCR dipreparasi dalam sumur agarose, kemudian dilakukan elektroforesis menggunakan tegangan 120 volt selama 20 menit. Hasil PCR dapat dilihat di Geldoc dengan menggunakan sinar UV transluminator.
Produk PCR kemudian dikirim ke FirstBase Singapura untuk dianalisis secara langsung. Hasil sekuensing DNA yang diperoleh, kemudian dianalisis menggunakan aplikasi MEGA 6.0 (Tamura et al. 2011) urutan sekuen yang dihasilkan kemudian diidentifikasi dengan menyelaraskan dengan data yang tersedia di Gene Bank di NCBI menggunakan BLAST dan kemudian membandingkan dengan urutan referensi.

\section{HASIL DAN PEMBAHASAN}

Bentuk morfologi Ikan Ekor Kuning (C. cuning) yang di daratkan di Pasar Muara Baru, Jakarta Utara dapat dilihat pada Gambar 2. Berdasarkan hasil pengamatan karakter morfologi, Ikan ekor kuning memiliki tubuh yang besar dan agak memanjang. Peristiwady (2006) menyatakan bahwa ikan ekor kuning (Caesio cuning) memiliki tubuh yang tinggi, agak panjang dan pipih. Mulut kecil dan terdapat sedikit gigi pada rahang, pada bagian depan rahang memiliki gigi berbentuk taring. Tubuh bagian atas berwarna biru agak kehitaman sedangkan pada bagian bawah rahang berwarna putih kebiruan. Sirip dada dan perut berwarna kemerahan. Ikan ekor kuning (C. cuning) memiliki rahang atas tunggal, biasanya 11 jari lunak pada sirip dubur, $45-51$ sisik gurat sisi, tubuh lebar, biru keabu-abuan dengan sirip ekor dan punggung bagian atas berwarna kuning, sisi bagian bawah dan kepala merah mudah dengan tanda kuning (White, et al.

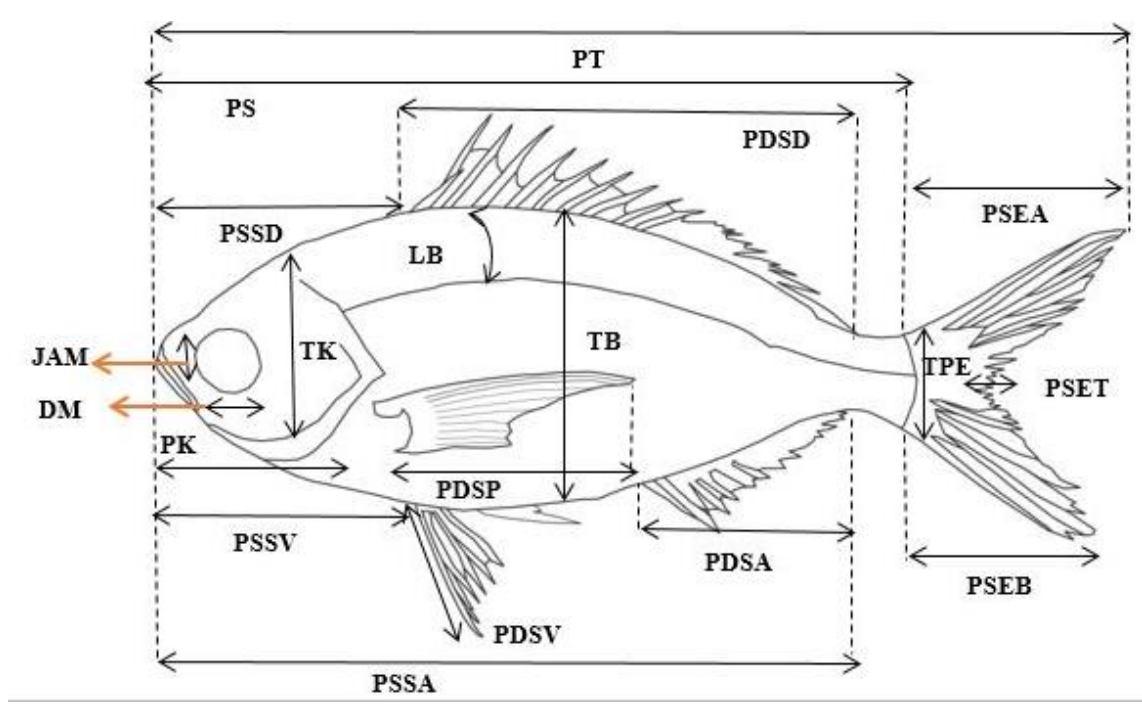

Gambar 1. Parameter Morfometrik Ikan Ekor Kuning (Caesio cuning) (Fitriadi et., 2012). 
2013). Ikan ekor kuning banyak terdapat pada area terumbu karang yang dicirikan dengan keadaan bawah air dengan visibilitas yang rendah. Caesio cuning merupakan spesies yang paling toleran terhadap air keruh dan biasanya ditemukan di daerah karang. spesies ini tersebar luas di daerah terumbu karang hingga ke dalam 60 $\mathrm{m}$ (Carpenter, 1998). Hasil analisis pengukuran dan perhitungan karakter morfometrik ikan ekor kuning (Caesio cuning) dapat dilihat pada Tabel 1.

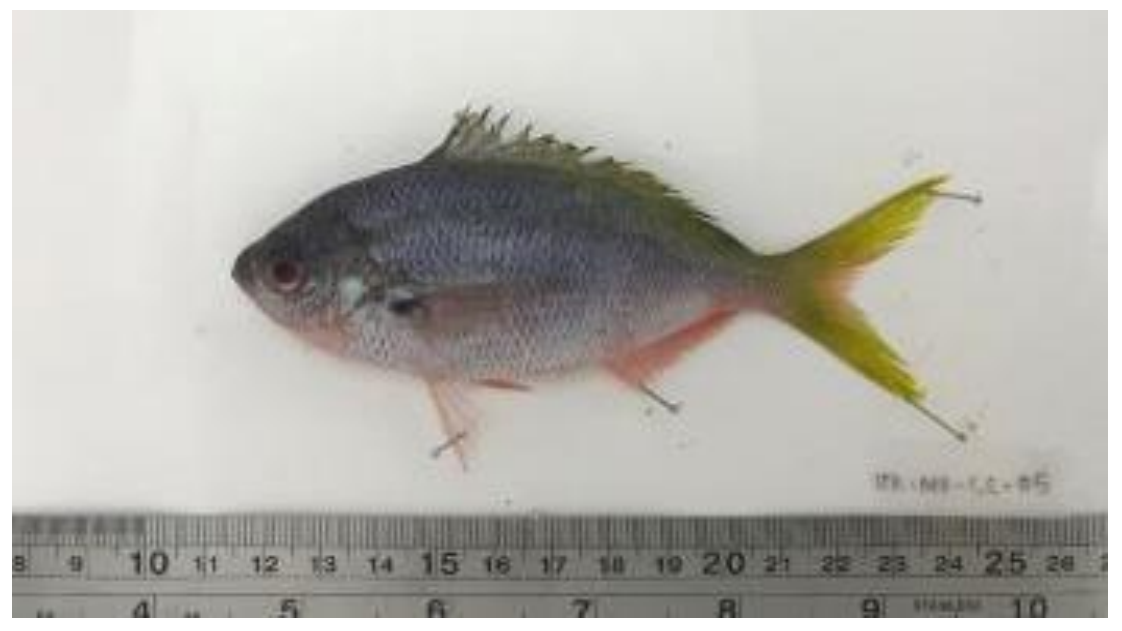

Gambar 2. Morfologi lkan Ekor Kuning (Caesio cuning)

Tabel 1. Hasil analisis karakter morfometrik

\begin{tabular}{cccc}
\hline Kode & Pengukuran & Min-Max $(\mathrm{cm})$ & Mean \pm SD \\
\hline PT & Panjang Total & $9,0-15,5$ & $13,3 \pm 1,23$ \\
PS & Panjang Standar & $8,5-11,6$ & $9,76 \pm 0,69$ \\
PK & Panjang Kepala & $2,5-3,3$ & $2,95 \pm 0,21$ \\
TK & Tinggi Kepala & $1,9-3.5$ & $2,87 \pm 0,43$ \\
TB & Tinggi Badan & $3,2-5,5$ & $3,96 \pm 0,62$ \\
TPE & Tinggi Pangkal Ekor & $0,8-1,8$ & $1,09 \pm 0,18$ \\
DM & Diameter Mata & $0,6-1,0$ & $0,82 \pm 0,11$ \\
JAM & Jarak Antar Mata & $1,0-1,8$ & $1,23 \pm 0,16$ \\
LB & Lebar Badan & $1,2-1,9$ & $1,45 \pm 0,17$ \\
PSSD & Panjang Sebelum Sirip Dorsal & $2,5-4,0$ & $3,34 \pm 0,42$ \\
PSSV & Panjang Sebelum Sirip & $2-3,8$ & $3,13 \pm 0,42$ \\
PSSA & Ventral & $2,5-7,9$ & $6,28 \pm 0,42$ \\
PDSD & Panjang Sebelum Sirip Anal & $4,7-6,3$ & $5,62 \pm 0,42$ \\
PDSA & Panjang Dasar Sirip Dorsal & $1,5-2,9$ & $2,31 \pm 0,34$ \\
PDSV & Panjang Dasar Sirip Anal & $1,4-2,8$ & $2,02 \pm 0,31$ \\
PDSP & Panjang Dasar Sirip Ventral & $2,1-3,5$ & $2,94 \pm 0,31$ \\
PSEA & Panjang Dasar Sirip Pectoral & $2,8-3,8$ & $3,22 \pm 0,22$ \\
PSET & Panjang Sirip Ekor Atas & $0,5-1,9$ & $1,39 \pm 0,40$ \\
PSEB & Panjang Sirip Ekor Tengah & $2,9-3,8$ & $3,27 \pm 0,25$ \\
\hline
\end{tabular}


Berdasarkan hasil pengukuran panjang total (PT) sampel ikan ekor kuning yang didaratkan di Pasar Muara Baru, Jakarta Utara memiliki kisaran panjang antara 9-15,5 $\mathrm{cm}$ dengan rata-rata $13,3 \pm 1,23$. Sebelumnya Padate et al. (2010) menemukan ukuran panjang total ikan ekor kuning di Perairan India dengan kisaran 7,49-10,05 cm. Dilokasi lain Gustomi et al. (2019) menemukan panjang total ikan ekor kuning dalam kisaran $12-18,3 \mathrm{~cm}$ dengan rata-rata $14,94 \mathrm{~cm}$. Selain itu, Zamani et al. (2011) melaporkan kisaran panjang ikan ekor kuning di Kepulauan Seribu yaitu 11,30-33,10 cm. Sebelumnya Indarsyah et al. (2010) melaporkan kisaran panjang ikan ekor kuning di Kepulauan Seribu yaitu 7,0-28 $\mathrm{cm}$ menggunakan alat tangkap jaring muroami. Perbedaan ukuran ikan yang ditemukan di setiap lokasi diduga disebabkan karena perbedaan karakteristik pada lokasi pengambilan sampel.

Menurut Fijaya (2002) salah satu faktor yang menyebabkan pertumbuhan yaitu habitat yang ditempati oleh ikan itu sendiri. Jumlah individu yang ada di ekosistem ikan sangat memberi pengaruh terhadap pertumbuhan, karena adanya kompetensi dalam mendapatkan makanan. Selain itu, ada beberapa faktor lain yang dapat mempengaruhi pertumbuhan ikan antara lain keturunan, jenis kelamin dan faktor umur dari ikan itu sendiri. Hasil sekuensing DNA ikan Ekor Kuning (Caesio cuning) menggunakan MEGA 6.0 (Tamura et al. 2011) menunjukkan bahwa terdapat 682 bp (Gambar 3).
Hasil BLAST menunjukkan komposisi pasangan basa masing-masing, T sebesar $27.4 \%$, C sebesar $28.3 \%$, A sebesar $25.7 \%$, dan $G$ sebesar $18.6 \%$. Persentase kemiripan species dengan data GenBank sebesar 99.10\% (Tabel 2).

Berdasarkan gambar 3 jumlah urutan basa nukleotida pada hasil sekuensing yaitu 682 pasangan basa. Hal ini dikarenakan primer yang digunakan pada target memiliki panjang basa $600 \mathrm{bp}$. Peneliti sebelumnya juga mendapatkan urutan pasangan basa pada ikan yaitu 650 bp untuk marka gen COI yang secara luas digunakan untuk identifikasi spesies, khususnya pada spesies kriptik dan identifikasi karakteristik morfologi yang masih membingungkan (Hubert et al. 2008; Aquilino et al. 2011; Sangciangco et al. 2011). Perbedaan panjang pasangan basa disebabkan oleh pemakaian jumlah sampel yang berbeda, namun hasil analisis sekuens pada sampel menunjukkan perubahan (Madduppa et al., 2016).

Berdasarkan hasil BLAST pada tabel 2 menunjukkan bahwa tingkat kemiripan $C$. cuning dengan database Gen Bank NCBI sebesar $99.10 \%$. Nilai max similaritas sebesar 99-100\% menunjukkan penjajaran yang signifikan bahwa ikan ekor kuning yang didapatkan di Pasar Muara Baru adalah genus dan spesies yang sama (Tindi et al. 2017). Selain itu, max score dan total score memiliki nilai yang sama yaitu 1199, query cover 97 dan E-Value 0.0. Menurut Triandiza

TTTCAACCAACCCACAAAGACATTGGCACCCTCTATTTAGTATTTGGTGCTTGAGCTGGA
ATGGTAGGCACAGCATTAAGCCTACTTATTCGAGCGGAACTAAGCCAACCAGGAGCTCT
TCTTGGAGACGACCAGATTTACAATGTAATTGTAACAGCACATGCATTTGTAATAATTTT
CTTTATAGTAATGCCAATTATGATCGGAGGATTCGGGAACTGACTGATTCCGCTAATGAT
CGGAGCACCCGACATGGCATTCCCCCGAATAAATAACATGAGCTTTTGACTTCTCCCCC
CATCATTCCTACTCTTACTCGCTTCCTCTGGAGTAGAGGCAGGGGCTGGAACTGGGTGA
ACAGTGTACCCCCCACTAGCAGGAAACCTCGCACACGCCGGAGCATCTGTTGACCTAAC
TATTTTCTCCCTCCACTTAGCAGGTGTTCCTCAATTCTAGGGGCTATCAACTTCATTACA
ACTATCATCAATATGAAACCTCCAGCTATTTCCAGTACCAAACACCACTGTTCGTTGA
GCCGTTCTAATTACCGCCGTCCTACTTCTTCTTTCCCTACCAGTCCTGGCTGCCGGAATTA
CAATGCTTCTTACAGACCGAAACCTAAATACAACCTTCTTGACCCAGCCGGAGGGGTG
ATCCCATCCTCTACCAGCCCTTCTG

Gambar 3. Hasil Sekuensing DNA 
Tabel 2. Hasil BLAST GenBank NCBI

\begin{tabular}{clllll}
\hline Deskripsi & Max Score & Total Score & $\begin{array}{c}\text { Query } \\
\text { Cover }\end{array}$ & Kemiripan & Akses NCBI \\
\hline $\begin{array}{c}\text { Caesio cuning cytochrome } \\
\text { oxidase subunit 1 (COI) } \\
\text { gene, partiall cds; }\end{array}$ & 1199 & 1199 & 97 & 99,10 & KF809392,1 \\
mitochondrial & & & & \\
\hline $\begin{array}{c}\text { Caesio cuning voucher } \\
\text { UG0044 cytochrome } \\
\text { oxidase subunit 1 (COI) } \\
\text { gene, partial cds; } \\
\text { mitochondrial }\end{array}$ & 1184 & 1184 & 95 & 99,54 & KP194254, \\
$\begin{array}{c}\text { Caesio cuning voucher } \\
\text { BW-A8720 cytochrome } \\
\text { oxidase subunit 1 (COI) }\end{array}$ & 1173 & 1173 & 95 & 99,23 & \\
gene, partial cds; & & & & \\
mitochondrial & & & & \\
\hline
\end{tabular}

dan Maddupa (2018) bahwa sekuen Bank gen yang paling mirip dicirikan dengan Max score dan Total score sama, Query coverage mendekati 100\%, E-value mendekati 0, dan Ident mendekati $100 \%$ pada setiap database. Hal ini menunjukkan bahwa spesies yang teridentifikasi berdasarkan marka gen $\mathrm{CO}$ merupakan ikan ekor kuning (Caesio cuning) dan termasuk dalam famili caesionidae.

Kemiripan hasil DNA yang diperoleh dengan database Gen Bank NCBI menunjukkan bahwa DNA barcoding merupakan salah satu alat alternatif yang dapat digunakan dalam proses identifikasi suatu spesies. Beberapa negara lain melaporkan teknik DNA telah sukses digunakan dalam autentikasi suatu spesies, seperti proses identifikasi 115 ikan di Perairan India (Lakra et al., 2011), 121 spesies di Perairan Chnia (Zhang et al., 2011) dan 207 spesies ikan di Austaralia (Ward, et al., 2007). Oleh karena itu, DNA barcoding memiliki peran yang penting dalam proses identifikasi spesies dengan akurat.

\section{KESIMPULAN}

Berdasarkan hasil morfologi ikan ekor kuning memiliki ciri khas dengan warna kuning di ekornya, analisis morfometrik menunjukkan ikan yang ditangkap masih berada pada fase juvenil. Analisis DNA ikan ekor kuning memiliki persentase kemiripan sebesar $99.10 \%$ dengan database GenBank NCBI. Metode DNA barcoding merupakan salah satu alternatif yang sangat efektif dalam melakukan identifikasi suatu spesies.

\section{DAFTAR PUSTAKA}

Aquilino, S.V., Tango, J.M., Fontanilla, I.K., Pagulayan, R.C., Basiao, Z.U., Ong, P.S. \& Quilang, J.P. 2011 . DNA barcoding of the ichthyofauna of Taal Lake, Philippines. Mol. Ecol. Res. 11: 612-619. doi: $10.1111 / \mathrm{j} .1755-0998.2011 .03000 . x$.

[BPS] Badan Pusat Statistik. 2008. Kepulauan Seribu dalam Angka 2007. Jakarta: Badan Pusat Statistik. $167 \mathrm{hlm}$.

Carpenter, K.C. 1998. Fusilier fishes of the world. An annotated and illustrated catalogue of caesionid species known to date. FAO Fisheries Synopsis (125) Vol. 8: $75 \mathrm{p}$.

Carpenter, K.E. 2001. Caesionidae (Fussiler). The Living Marine Resources of the Western Central Pacific. Volume 5. Bony Fishes Part 3 (Menidae to Pomacentridae). Food and Agriculture Organization of theUnited Nations, Rome.

[DEPTAN] Departemen Pertanian. 1998. Perikanan Musim Penangkapan Ikan. Buletin Warta Mina No. 65, 66, 68, 71, 72 dan 73. Jakarta: Dirjen Perikanan.

Fijaya, Y. 2002. Fisiologi Ikan. Direktorat Jenderal Pendidikan Tinggi Depdiknas: Jakarta. 
Fitriadi A.F, R. Elvyra \& Yusfiati. 2012. Morfometrik dan Meristik ikan parang parang (Chirocentrus dorab Forsskal, 1775) di perairan Bengkalis. Biologi, Universitas Riau.

Gustomi, A., Arizona, A. \& Akhrianti, I. 2019. The Study of Morfometric and Meristic of Yellow Tail Fish Landed in Nusantara Fishery Harbour of Sungailiat. Earth Environ. Sci., 353. doi: 10.1088/17551315 /353/1/012057.

Hebert, N., Ratnasingham, S. \& DeWaard, J.R. 2003. Barcoding animal life: Cytochrome c oxidase subunit 1 divergences among closely related species. Proc. Royal Soc. Biol. Sci., 270(SUPPL. 1):96-99. doi: 10.1098/ rsbl.2003.0025.

Hubert. N,, Hanner. R. Holm, E., Mandrak, N.E., \& Taylor, E. 2008. Identifying Canadian freshwater fishes through DNA barcodes. PLoS One, 3(6):e2490. doi: 10.1371/jour nal.pone.0002490.

Indarsyah, I.J., Hartati, S.T. \& Wahyuni, I.S., 2010. Pertumbuhan, sebaran ukuran panjang, dan kematangan gonad ikan ekor kuning (Caesio cuning) di perairan Kepulauan Seribu. Prosiding seminar Nasional Ikan VI dan Kongres Masyarakat Ikhtiologi Indonesia III, Cibinong, September 8.

Johnson, G.D., 1980. The limits and relationships of the Lutjanidae an associated families. Bulletin of the Scripps Institution of Oceanography: University of California.

Lakra, W.S., Verma, M.S., Goswami, M., Lal, K.K., Mohindra, V., Punia, P., Gopalakrishman, A., Singh, K.V., Ward, R. D. \& Hebert, P.N.D. 2011. DNA barcoding Indian marine fishes. Mol. Ecol. Res., 10:60-71. doi: $10.1111 /$ j.17550998.2010.02 894.x.

Madduppa, H. 2014. Bioekologi dan Biosistematika Ikan Terumbu. PT IPB Press: Bogor.

Madduppa, H., Ayuningtyas, R. U., Subhan, B. \& Arafat, D. 2016. Exploited but unevaluated: DNA barcoding reveals skates and stingrays (Chordata, Chondrichtyes) species landed in the Indonesia fish market. International J. Mar. Sci., 21 (2): 77-84. doi: 10.14710/ik. ijms.21.2.77-84.
Padate, V.P., Rivonker, C.U., Anil, A.C. 2010. A note on the occurrence of reef inhabiting, red-bellied yellow tail fusilier, Caesio cuning from outside its known geographical array. Mar. Biodiv. Rec., (3): 1-7. doi: 10.11609/jott.3620.1013.12844-12 846

Peristiwady, T. 2006. Ikan-ikan Laut Ekonomis Penting di Indonesia. LIPI Press: Jakarta, Indonesia. 270 hal.

Sanciangco, M.D., Rocha, L.A. \& Carpenter, K.E. 2011. A molecular phylogeny of the Grunts (Perciformes: Haemulidae) inferred using mitochondrial and nuclear genes. Zootaxa, 2966(7):37-50. doi: 10.11646/zootaxa.2966.1.4.

Tindi, M., Mamangkey, N.G.F. \& Wulur, S. 2017. DNA barcode dan analisis filogenetik molekuler beberapa jenis bivalvia asal perairan Sulawesi Utara berdasarkan gen COI. J. Pesisir Laut Tropis., (2): 32-39. doi: 10.35800/jplt.5.2.2017.15050.

Triandiza, T. \& Madduppa, H. 2018. Aplikasi Analisa Morfologi dan Dna Barcoding Pada Penentuan Jenis Kepiting Porcelain (Pisidia sp.) Yang Berasal Dari Pulau Tunda, Banten. Jurnal Sumberdaya Akuatik Indopasifik. 2(2):81-90.

Tamura, K., Peterson, D., Peterson, N., Stecher, G., Nei, M. \& Kumar, S. 2011. Mega 5: Molecular Evolutionary Genetics Analysis Using Maximum Likelihood, Evolutionary Distance, And Maximum Parsimony Methdos. Mol. Biol. Evol.,28(10):2731-2739. doi: 10.1093/molbev/msr 121 .

Ward, R.D., Zemlak, T.S., Innes, B.H., Last, P.R., Hebert, P.D.N. 2005. DNA barcoding Australia's fish species. Philosophic. Transac. Royal Soc. Biol. Sci., 360 (1462):1847-1857. doi: 10.3354/ab00068

Ward, R.D., Connel, A.D., Holmes, B.H. \& Steinke, D. 2008. DNA barcoding of shared fish species from the North Atlantic and Autralasia: minimal divergence for most taxa, but Zeus faber and Lepidopus caudatus each probably consititute two species. Aqua. Biol. (3):7178.

White, W.T., Last, P.R., Dharmadi, Faizah, R., Chodrijah. U., Prisantoso, B. I., Pognoski. J.J., Puckridge, M. \& Blaber, S.J.M. 2013. Market fishes of Indonesia (jenis-jenis ikan di Indonesia). ACIAR Monograph No. 155. 
Australian Centre for International Agricultural Research: Canbera. 438 pp.

Zamani, N.P., Wardiatno, Y. \& Nggajo, R. 2011. Strategi Pengembangan Pengelolaan Sumberdaya Ikan Ekor Kuning (Caesio cuning) Pada Ekosistem Terumbu Karang
Di Kepulauan Seribu. J. Sains Teknol. Perikan., 6(2):38-51.

Zhang, J. 2011. Species identification of marine fishes in China with DNA barcoding. Evid. Based Complementary Altern. Med., 10:1-10. doi: 10.1155/2011/9 78253 